\title{
The Book of Ruth and the Limits of Proverbial Wisdom
}

\author{
Laura Quick \\ University of Oxford \\ laura.quick@theology.ox.ac.uk \\ Worcester College \\ Walton Street \\ Oxford \\ OX12HB \\ United Kingdom
}

The intertextual connections which the book of Ruth makes to the book of Proverbs, and in particular to the Valiant Woman of Proverbs 31, suggests that the author intended the narrative to be read in a particular way. The canonical context of the book of Ruth, situated alongside Proverbs in the Writings, is a recognition of this, as is the modern reception of Ruth as an exegesis or actualization of the Valiant Woman character. But in this essay, I argue that this latter reading strategy fails to capture exactly how Ruth relates to the book of Proverbs and to the wisdom genre in general. In contrast to commentators who have interpreted the book as a demonstration of wisdom values within a narrative setting, I suggest that the book of Ruth can be understood as an extended problematization of the limits of wisdom expressed in categorizing discourse. Ruth attempts a destabilization of some of the authoritative claims made about conventional wisdom as expressed in the book of Proverbs. Categories of conventional wisdom are set up, only to be destabilized and complicated throughout the text. This reading of the book of Ruth brings it much closer to the other two texts which make up Israelite wisdom literature: the books of Job and Qoheleth, which also reflect upon and complicate conventional wisdom. Ruth can therefore be understood in relation to the wisdom genre - but the relationship is more complex and nuanced than commentators have hitherto realized.

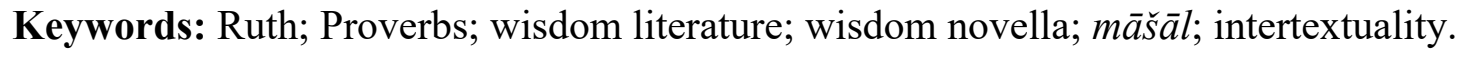




\section{The Book of Ruth and the Limits of Proverbial Wisdom ${ }^{1}$}

\section{Introduction}

Characterizing the book of Ruth, Johann Wolfgang von Goethe called it "the loveliest little epic and idyllic entity."2 Words like "epic" and "idyllic" are indicative of the reading strategy or rhetorical orientation that Goethe took when approaching the book of Ruth: they make claims about the genre of the narrative, and following Goethe the book has often been labelled a novel, novella, folktale, or short story. ${ }^{3}$ Yet there is an indecision among commentators concerning how

${ }^{1}$ With thanks to Jacqueline Vayntrub, who shared a pre-publication copy of her book with me. English Bible translations are based on the New English Translation (NETS), with alterations made by the author where necessary.

${ }^{2}$ Johann Wolfgang von Goethe, "Noten und Abhandlungen zu besserem Verständnis des west-östlichen Divans," in Goethe West-östlicher Divan, ed. Hans-Joachim Weitz (Frankfurt: Insel-Verlag, 1986), 1-249, here 129.

${ }^{3}$ On Ruth as a "novel” see already Hermann Gunkel, "Ruth,” in Reden und Aufsätze (Göttingen: Vandenhoeck \& Ruprecht, 1913), 84-6. There is a general imprecision in the terminology employed, compare for example Edward F. Campbell, “The Hebrew Short Story: A Study of Ruth," in A Light unto My Path: Old Testament Studies in Honor of Jacob M. Myers, ed. Howard W. Bream, Ralph D. Heim and Carey A. Moore (Philadelphia, PA: Temple University Press, 1974), 83-101; Erich Zenger, Das Buch Ruth, ZBKAT 8 (Zürich: Theologischer Verlag, 1986), 22-25; Frederic Bush, Ruth/Esther, WBC 9 (Nashville, TN: Thomas Nelson, 1996), 30-47; Robert L. Hubbard, The Book of Ruth, NICOT (Grand Rapids, 
exactly the "short stories" of the Hebrew Bible should be understood. These texts have sometimes been related to the Israelite wisdom tradition and accordingly given titles such as "wisdom novella" or "wisdom narrative." For example, the book of Ruth has been compared to the acrostic poem praising the Valiant Woman in Prov 31:10-31. Erich Zenger has described Ruth as a form of canonical exegesis on the Valiant Woman character. ${ }^{4}$ He suggests that the book serves as a demonstration of the feminine ideals illustrated in Proverbs 31 , and hence must be understood as a weisheitliche Novelle, a "wisdom novel." Though few would express the

MI: Eerdmans, 1988), 47; Jack M. Sasson, Ruth: A New Translation with a Philological Commentary and a Formal-Folklorist Interpretation (2nd ed.; Sheffield: Sheffield Academic Press, 1989), 214; Kirsten Nielsen, Ruth: A Commentary, trans. Edward Broadbridge, OTL (Louisville, KY: Westminster Kohn Knox, 1997), 5; Carolyn Pressler, Joshua, Judges, and Ruth, WBC (Louisville, KY: Westminster John Knox, 2002), 261; André LaCocque, Ruth: A

Continental Commentary, trans. K.C. Hanson (Minneapolis, MN: Fortress, 2004), 9; and Tamara Cohn Eskenazi and Tikva Frymer-Kensky, Ruth: The Traditional Hebrew Text with the New JPS Translation Commentary, JPS Bible Commentary (Philadelphia, PA: Jewish Publication Society, 2011), xix-xx.

${ }^{4}$ Erich Zenger, Einleitung in das Alte Testament, KStTh (Stuttgart: Kohlhammer, 2004), 28.

${ }^{5}$ Ibid, 333. In a similar vein, Otto Kaiser describes the book as weisheitliche Lehrerzählung, "wisdom teaching" (Grundriß der Einleitung in die kanonischen und deuterokanonischen Schriften des Alten Testaments, Bd. 1, Die erzählenden Werke [Gütersloher: Mohn, 1992], 152). Timothy J. Stone has made a complementary argument on the basis on the 
relationship of the book of Ruth to wisdom literature in quite such explicit terms, a number of other scholars have read Ruth as a text written in order to motivate the reader to emulate the behavior of the Valiant Woman. ${ }^{6}$ Katharine Dell, for example, describes her as a "profound exemplar" of the values embodied in proverbial wisdom, although she explicitly refuses to engage into the debate as to whether Ruth is a "wisdom novella of some kind."

canonical context of the book, since both Ruth and Proverbs are placed within the Writings (alongside Song of Songs, Qoheleth, Lamentations, and Esther). He therefore suggests reading Ruth within a wisdom framework (The Compositional History of the Megilloth: Canon, Contoured Intertextuality and Meaning in the Writings, FAT II/59 [Tübingen: Mohr Siebeck, 2013], 130-7).

${ }^{6}$ For example, Edward F. Campbell, Ruth: A New Translation with Introduction, Notes, and Commentary, AB 7 (New York, NY: Doubleday, 1975), 29-30; cf. Ernst Würthwein, Die Fünf Megilloth: Ruth, das Hohelied, Esther, der Prediger, die Klagelieder, HZAT (Tübingen: Mohr Siebeck, 1969), 5-6; Hubbard, The Book of Ruth, 65-66, 72-74; E. John Hamlin, Surely There is a Future: A Commentary on the Book of Ruth, ITC (Grand Rapids, MN: Eerdmans, 1996), 16, 78; Katherine Doob Sakenfeld, Ruth: A Bible Commentary for Teaching and Preaching, Interpretation (Louisville, KY: John Knox, 1999), 1, 11-13, 24, 47-48, 61-64; Andrea Beyer, Hoffnung in Bethlehem: Innerbiblische Querbezüge als Deutungshorizonte im Ruthbuch, BZAW 463 (Berlin: de Gruyter, 2010), 161-68.

${ }^{7}$ Katharine J. Dell, "Didactic Intertextuality: Proverbial Wisdom as Illustrated in Ruth," in Reading Proverbs Intertextually, ed. Katharine J. Dell and Will Kynes, LHBOTS 629 (London: Bloomsbury T\&T Clark, 2019), 103-114, here 104. 
This reception of the book in Ruth as a "wisdom novella," or at least related to the genre of wisdom literature in some way, touches upon something implicit within the story. The purpose of this study is to outline those elements that give Ruth its wisdom dimension, and beyond that, to consider how exactly Ruth relates to the wisdom tradition. Nevertheless, we must be sensitive to the issues that come along with talking about literary categories and genre in ancient texts. In the following, I aim at a discussion of the book of Ruth which is sensitive to these problems. Attempting an emic approach to biblical genre, I utilize an intertextual method that compares the language and themes of the book of Ruth to that of Proverbs. Indeed, the book of Ruth explicitly draws upon the language of Proverbs, and a number of phrases are found only in these two books. But in contrast to commentators who have consequently interpreted the book as a demonstration of wisdom values within a narrative setting, Ruth frequently subverts and hence problematizes our expectations of these values. I argue that the book of Ruth attempts a destabilization of some of the authoritative claims made about conventional wisdom as expressed in the $m \bar{a} \check{s} \bar{a} l$, the proverbial form ultilized in the book of Proverbs. This interpretation is dependent upon recent discussions of the $m \bar{a} s ̌ a \bar{l} l$ form by Jacqueline Vayntrub, who characterizes the $m \bar{a} s ̌ \bar{a} l$ as a type of speech performance governed by parallelism, the prosody of which establishes categories and makes hierarchical claims about the relationships between those categories. The world understood in such a way is governed by binaries: the $m \bar{a} \check{s} \bar{a} l$ encourages an uncompromising, unequivocal worldview. ${ }^{8}$ The book of Ruth draws upon some of the categories

${ }^{8}$ See Jacqueline Vayntrub, Beyond Orality: Biblical Poetry in its Own Terms, The Ancient Word: New Discoveries in Religion and Language from the Biblical and Near Eastern World (London and New York, NY: Routledge, 2019), esp. 70-71, 145, 164, 170, 172. 
developed by the book of Proverbs, but utilizes the prose narrative form in order to explore the limitations of categorizing discourse. Though it is conventionally compared to the book of Proverbs, I interpret Ruth as a meditation on the limitations of Proverbial wisdom, and hence suggest that other wisdom texts such as Qoheleth and Job provide a more obvious point of comparanda. Ruth can therefore be understood in relation to the wisdom genre - but the relationship is more complex and nuanced than commentators have hitherto realized.

\section{Ruth as Wisdom Novella}

In the Second Temple period a number of texts arose that are characterized by brevity, narrative consistency, and literary artistry: from the Hebrew Bible, we might include the Joseph story (Genesis 37-50), the books of Jonah, Esther, and Ruth, and the stories about Daniel (Daniel 1-6). Accordingly, these "novella" texts are often treated together, as if they comprise a literary genre or corpus of their own. It is therefore impossible to discuss treatments of the genre of the book of Ruth apart from wider discussions concerning the genre of these texts. A principal strategy for understanding these books is to refer them to the category "wisdom literature," understanding these stories as demonstrating wisdom values within a narrative setting. The texts typically acknowledged as wisdom literature include the books of Proverbs, Job, and Qoheleth from the Hebrew Bible, alongside Wisdom of Solomon and Ben Sira from the Greek Bible - although as we shall go on to see, the precise make-up of this canon is debated. As a minimal description, wisdom literature can be defined as a mode of discourse concerned with the skill of language and good living. Often this discourse is characterized by the instructional form and as a corollary, by

literary representations of the father-to-son or teacher-to-student relationship, although this is not 
an exclusive feature of the genre either. This latter characterization would not include the book of Job, for example - and certainly not the novella texts which are the subject of this inquiry. The primary proponent for reading the novella as wisdom literature was Gerhard von Rad, who based his analysis on the Joseph story. According to von Rad, the Joseph story is a manifestation of early wisdom with close links to Proverbs. The story was composed to embody the educational ideals of wise men, the scribes whom he supposed to have been active in the royal court during the early monarchy. For von Rad, rather than a text which had been influenced by the wisdom tradition, the Joseph story should be understood as an example of wisdom literature. ${ }^{9}$ He therefore broadened the category of biblical wisdom literature from comprising merely the books of Proverbs, Qoheleth, and Job, to include other texts too, opening up the

\footnotetext{
${ }^{9}$ Gerhard von Rad, "Josephsgeschichte und ältere Chokma," in Gesammelte Studien zum Alten Testament, TB 8 (München: C. Kaiser, 1958), 272-80. Von Rad's conclusions were followed by C.T. Fris, “God Was With Him," Int 9 (1955): 21-32; Roland de Vaux, Histoire ancienne d'Israël, Vol. I: Des origines à l'installation en Canaan (Paris: J. Gabalda \& Co., 1971), 281; and Jaap P.H. Wessels, “The Joseph Story as a Wisdom Novelette," OTE 2 (1984): $39-60$.
} 
possibility that narrative ${ }^{10}$ and psalms ${ }^{11}$ could also be understood as wisdom literature. Indeed, Shemaryahu Talmon went on to make a similar case for the book of Esther. ${ }^{12}$ Both the Joseph Story and the book of Esther are set in the royal court. It is therefore easy to see how von Rad and Talmon could interpret them as embodying or enacting a key theme of wisdom literature: the

${ }^{10}$ Von Rad made a similar suggestion for the "succession narrative," 2 Samuel 9-20 and 1 Kings 1-2, and was followed by Roger Whybray. See Gerhard von Rad "Der Anfang der Geschichtsschreibung im alten Israel," Archiv für Kulturgeschichte 32 (1944): 1-42, here 12; and Roger N. Whybray, The Succession Narrative: A Study of II Samuel 9-20, 1 Kings 1-2, SBT 2/9 (London: SCM, 1968). For a discussion and critique of this interpretation, see esp. David M. Gunn, Story of King David: Genre and Interpretation, JSOTSup 6 (Sheffield: Sheffield Academic Press, 1978), 26-9. The book of Jonah has also been described as a form of "narrative wisdom" (e.g. by Ernst Sellin and Georg von Fohrer, Einleitung in das Alte Testament [10th ed.; Heidelberg: Quelle \& Meyer, 1965], 485-6). This interpretation has been discussed with approval by George M. Landes, “Jonah: a Māšāl?” in Israelite Wisdom: Theological and Literary Essays in Honor of Samuel Terrien, ed. John G. Gammie et al. (Missoula, MT: Scholars Press, 1978), 149-50.

11 The detection of a wisdom influence within the Psalter began already with Hermann Gunkel (Die Psalmen übersetzt und erklärt, GHAT II/2 [Göttingen: Vandenhoeck \& Ruprecht, 1926]). For a recent reconsideration of the "wisdom psalms" as a genre, see Simon Chi-Chung Cheung, Wisdom Intoned: A Reappraisal of the Genre 'Wisdom Psalms,' LHBOTS 248 (London: T\&T Clark, 2015).

12 Shemaryahu Talmon, “'Wisdom' in the Book of Esther,” VT 13 (1963): 419-55. 
wisdom of scribes or courtiers. ${ }^{13}$ But this is quite different from the setting of the book of Ruth. Instead, a number of scholars have connected Ruth to the Valiant Woman of Proverbs $31,{ }^{14}$ and have accordingly read the book as a text written in order to motivate the reader to emulate the behavior of the Valiant Woman, although few would go so far as to explicitly designate Ruth as wisdom literature. ${ }^{15}$ In fact, many scholars have issued a stringent critique against the existence of a genre "narrative wisdom." ${ }^{.16}$ For example, on the basis of his assessment that wisdom

${ }^{13}$ Ibid, 426-7.

${ }^{14}$ See e.g. Campbell, Ruth, 29-30; Thomas P. McCreesh, "Wisdom as Wife: Proverbs 31:10-31," RB 92 (1985): 25-46; Sakenfield, Ruth, 62; Samuel T.S. Goh, "Ruth as Superior Woman of hyl? A Comparison Between Ruth and the 'Capable' Woman in Proverbs 31:10-31," JSOT 38 (2014): 487-500; Gregory Goswell, “Is Ruth Also Among the Wise?" in Exploring Old Testament Wisdom: Literature and Themes, ed. David G. Firth and Lindsay Wilson (London: Apollos, 2016), 115-33, here 122. Katharine Dell has explored thematic links shared between the book of Ruth with the proverbial maxims of Proverbs 10-30. She considers Proverbs 10-30 and the book of Ruth to share a concern for friendship, family loyalty, hard work, obedience and redemption, among various other themes. See Dell, "Didactic Intertextuality."

${ }^{15}$ E.g. Campbell, Ruth, 29-30; cf. Würthwein, Die Fünf Megilloth, 5-6; Hubbard, The Book of Ruth, 65-66, 72-74; Hamlin, Surely There is a Future, 16, 78; Sakenfeld, Ruth, 1, 11-13, 24, 47-48, 61-64; Beyer, Hoffnung in Bethlehem, 161-68.

${ }^{16}$ See e.g. James L. Crenshaw, "Method in Determining Wisdom Influence upon 'Historical' Literature,’ JBL 88 (1969): 129-42; Donald B. Redford, A Study of the Biblical Story of Joseph, VTSup 20 (Leiden: Brill, 1970), 100-105; George W. Coats, “The Joseph Story and 
literature is "a well-defined genre of instructional texts whose exemplars share characteristic assumptions, principles, and literary formulations," Michael Fox cautioned that although there are indeed wisdom themes in the Joseph story, it is not wisdom literature: it reflects significantly different attitudes and assumptions from the "well-defined genre" embodied by Proverbs, Qoheleth, and Job. ${ }^{17}$ For Fox, the identification of "wisdom themes" in texts such as the Joseph story or book of Esther does not necessitate their inclusion in the category wisdom literature, nor is it even particularly helpful in terms of our generic expectations for these texts: the identification of wisdom themes in texts outside of the "canon" of wisdom literature says little about the interpretative stance that a reader should take when approaching that book. ${ }^{18}$

Part of the problem here relates to the difficulty of describing genre in biblical literature in general. Unlike academics who deal with Classical literature, scholars of the Hebrew Bible have no native literary criticism or theory through which to view biblical texts. Instead, scholars

Ancient Wisdom: A Reappraisal,” CBQ 35 (1973): 285-97; Claus Westermann, Genesis 37-50:

A Continental Commentary, trans. John J. Scullion (Minneapolis, MN: Fortress, 1986), 26-27, 247-48; Stuart Weeks, Early Israelite Wisdom, Oxford Theological Monographs (Oxford: Oxford University Press, 2000), 92-109; Michael V. Fox, "Wisdom in the Joseph Story," VT 51 (2001): 26-41; Kevin McGeough, “Esther the Hero: Going beyond 'Wisdom' in Heroic Narratives," CBQ 70 (2008): 44-65.

${ }^{17}$ Fox, "Wisdom in the Joseph Story," 29.

${ }^{18}$ Michael V. Fox, Character and Ideology in the Book of Esther, Studies on Personalities of the Old Testament (Columbia, TN: University of South Carolina Press, 1991), 142-3. 
have had to import conventions derived from ancient Greek literature, or to derive these conventions themselves by searching for interconnections among ancient texts. This latter strategy is what gave rise to the idea of "wisdom literature," based initially on a recognition of the apparent thematic and especially formal similarities shared between the books of Proverbs, Job, and Qoheleth. Yet here too there are certain perils. If no biblical texts engage in a selfreflective discussion of the boundaries and delimitations of a genre "wisdom literature," how are scholars supposed to know which texts should be included? This is apparent in the disagreement concerning whether texts like the Joseph story or the book of Esther can be considered "wisdom literature." But more generally, the existence of a category of "wisdom literature" itself has come increasingly under threat. Certainly the existence of a "well-defined genre," as Fox was able to claim as recently as 2001, appears ever more controversial. Criticisms have been leveled at the old form-critical assumptions that saw scholars leap from the isolation of a genre "wisdom literature" to posit the existence of "wisdom schools" tasked with its creation. ${ }^{19}$ In particular, the criteria of form alone as the basis for the recognition of a wisdom text is problematic. As Jacqueline Vayntrub has demonstrated, there is a developmental or evolutionary assumption which has underpinned many scholarly discussions of wisdom literature. The book of Proverbs is

${ }^{19}$ See e.g. Mark R. Sneed, “Is the 'Wisdom Tradition' a Tradition?” CBQ 73 (2011): 5071; Stuart Weeks, “Wisdom, Form and Genre," in Was There a Wisdom Tradition? New Prospects in Israelite Wisdom Studies, ed. Mark R. Sneed, Ancient Israel and Its Literature 23 (Atlanta, GA: SBL, 2015), 161-77; Jacqueline Vayntrub, “The Book of Proverbs and the Idea of Ancient Israelite Education," ZAW 128 (2016): 96-114. 
a collection of sayings that utilize the משל $m \bar{a} \check{s} \bar{a} l$, usually translated as "proverb." 20 This has often been taken to be the earliest and most characteristic form of Israelite wisdom, with further elaborations upon the genre then developed in the books of Qoheleth and Job (as well as in the wisdom teaching of the New Testament). ${ }^{21}$ But beyond any tidy evolutionary schema, the texts categorized as wisdom literature are notoriously difficult to date. The book of Proverbs is a case in point, and in fact Proverbs 1-9, explicitly designated as $m \bar{a} s ̌ a ̄ l$ within the text, is often understood to have been compiled at a much later point than the rest of the book of Proverbs. ${ }^{22}$ Job, Qoheleth, and Proverbs are clearly characterized by similar themes and concerns, even if they do develop diverse literary forms. It is now recognized that form alone, especially understood exclusively through the lens of the Proverbial framework, is insufficient as the sole criteria with which to assess the wisdom dimension of a literary work.

${ }^{20}$ On the difficulty of translating this lexeme, see Jacqueline Vayntrub, “"To Take Up a Parable': The History of Translating a Biblical Idiom,” VT 66 (2016): 627-45.

${ }^{21}$ See e.g. Raymond C. van Leeuwen, "Proverbs, Book of," in Dictionary for the Theological Interpretation of the Bible, ed. Kevin J. Vanhooser et al. (Grand Rapids, MI: Baker Academic, 2005), 638-41, here 638; cf. Norbert Lohfink, who calls Proverbs the "first-level" of wisdom literature (Qoheleth: A Continental Commentary, trans. Sean McEvenue [Minneapolis, MN: Fortress, 2003], 13). For Vayntrub's critique of this evolutionary schema, see Jacqueline Vayntrub, "Wisdom in Transmission: Rethinking Ben Sira and Proverbs," in Proceedings of the Ben Sira Conference, July 2017, ed. Gregory Goering, Matthew Goff and Samuel Adams, JSJSup (Leiden: Brill, forthcoming).

${ }^{22}$ See e.g. Fox, Proverbs 1-9, 48-49. 
It is this unease with current methodologies for understanding generic conventions in biblical literature that has seen scholars such as Hindy Najman attempt to provide new answers to the question: "how can we use the term 'genre' in traditions that do not conform to the institutional constraints of Greek and Roman writing?"23 One heuristic in particular is useful in the context of this study: the search for constellations of features shared between texts, variously called "intertextuality" or "family resemblances." Of course, this is precisely what led to the recognition of the genre wisdom literature in the nineteenth century in the first place. But as we have seen, these studies were often conducted under an explicitly form-critical perspective, with the $m \bar{a} \check{s} \bar{a} l$ understood as prototypical. ${ }^{24}$ What I am gesturing to here instead is the particular nuance made to this method by scholars such as Najman, ${ }^{25}$ alongside Will Kynes, Katharine

${ }^{23}$ Hindy Najman, “The Idea of Biblical Genre: From Discourse to Constellation,” in Prayer and Poetry in the Dead Sea Scrolls and Related Literature: Essays in Honor of Eileen Schuller on the Occasion of Her 65th Birthday, ed. Jeremy Penner at al., STDJ 98 (Leiden: Brill, 2012), 307-21, here 307.

${ }^{24}$ On early studies of wisdom literature, see Will Kynes, "The Nineteenth-Century Beginnings of 'Wisdom Literature,' and Its Twenty-First Century End?” in Perspectives on Israelite Wisdom: Proceedings of the Oxford Old Testament Seminar, ed. John Jarick, LHBOTS 618 (London: Bloomsbury T\&T Clark, 2016), 83-108; idem, An Obituary for 'Wisdom Literature': The Birth, Death, and Intertextual Reintegration of a Biblical Corpus (Oxford: Oxford University Press, 2019), 60-104.

${ }^{25}$ Najman proposes a consideration of "constellations of features or elements" in Najman, “The Idea of Biblical Genre," 316 (emphasis in original). 
Dell, and Mark Sneed working in the field of wisdom literature explicitly. Kynes cautions against speaking of genres as categories, "as defining what a text is rather than the group of texts with which it shares some salient similarity." Thus "Wisdom is a genre grouping for these texts rather than the genre category for them." ${ }^{26}$ In a number of publications, Kynes has couched this move in terms of intertextuality:

I would prescribe that the so-called Wisdom genre can no longer be considered the exclusive categorization for the books it purportedly contains nor the grounds on which to draw conclusions about movements to which their authors belonged, but simply one of the many ways to draw intertextual connections among them and other texts in the Hebrew Bible. ${ }^{27}$

${ }^{26}$ Kynes, An Obituary for 'Wisdom Literature,' 19 (emphasis in original).

${ }^{27}$ Will Kynes, “The Modern Scholarly Wisdom Tradition and the Threat of PanSapientialism: A Case Report," in Was There a Wisdom Tradition? New Prospects in Israelite Wisdom Studies, ed. Mark R. Sneed, Ancient Israel and Its Literature 23 (Atlanta, GA: SBL, 2015), 11-38, here 31. Kynes has co-edited a number of books on the intertextual connections between wisdom literature and the wider canon. See Will Kynes and Katharine J. Dell, eds. Reading Job Intertextually, LHBOTS 574 (London: Bloomsbury T\&T Clark, 2013); idem, eds. Reading Ecclesiastes Intertextually, LHBOTS 587 (London: Bloomsbury T\&T Clark, 2014); idem, eds. Reading Proverbs Intertextually, LHBOTS 629 (London: Bloomsbury, 2018). The term "intertextuality" was coined by Julia Kristeva, derived from her reading of the work of Mikhail Bakhtin mediated by the texts of Jacques Derrida and Jacques Lacan. See Julia Kristeva, 
Thus the genre "wisdom literature" is a useful heuristic for describing interconnections among certain ancient texts - genre is after all the formalization of intertextual comparisons made by readers $^{28}$ — without denying their connections to a whole network of other textual associations. This recalls Molly Zahn, who speaks of texts "participating in genres: dipping into them, employing their elements in modified fashion, combining them. In this model, texts can participate in multiple genres simultaneously." 29 It also recalls the approach to Wittgenstein's concept of "family resemblances" made by some scholars: Sneed, for example, notes that all the books usually designated as wisdom literature (presumably Proverbs, Job, and Qoheleth) share a "family resemblance" - as well as striking differences, too. ${ }^{30}$ Texts can be grouped according to family resemblances, but we must recognize that they may take part in multiple "families."

Desire in Language: A Semiotic Approach to Literature and Art, trans. Thomas Gora et al. (New York, NY: Columbia University Press, 1980).

${ }^{28}$ Carol A. Newsom, "Pairing Research Questions and Theories of Genre: A Case Study of the Hodayot," DSD 17 (2010): 270-88, here 273.

${ }^{29}$ Molly Zahn, “Genre and Rewritten Scripture,” JBL 131 (2012): 271-88, here 277.

${ }^{30}$ Mark R. Sneed, “'Grasping After the Wind:' The Elusive Attempt to Define and Delimit Wisdom," in Was There a Wisdom Tradition? New Prospects in Israelite Wisdom Studies, ed. Mark R. Sneed, Ancient Israel and Its Literature 23 (Atlanta, GA: SBL, 2015), 3967, here 62; cf. Katharine J. Dell, “Deciding the Boundaries of 'Wisdom:' Applying the Concept of Family Resemblance," in Was There a Wisdom Tradition? New Prospects in Israelite Wisdom Studies, ed. Mark R. Sneed, Ancient Israel and Its Literature 23; (Atlanta, GA: SBL, 2015), 145 - 
What are the implications of these moves for studying the book of Ruth? On the one hand, the move towards intertextuality tasks us with an investigation of the intertextual links shared between Ruth and other texts. At the same time, we must do away with any taxonomic understanding of genre. The existence of a "well-defined" category with which to assess biblical texts in order to sort them into categories - wisdom or non-wisdom — is not helpful here. This opens up the possibility that the book of Ruth may indeed share characteristics with texts traditionally understood as wisdom literature, even though as a prose narrative it does not share all of their formal characteristics. Beyond structural considerations, thematic and linguistic connections might suggest that a text be read in light of the wisdom tradition - and this can be helpful in uncovering the intentions and conventions encoded in the text. In the following, I examine the language and themes of Ruth against the background of some of the lexical and aesthetic strategies employed in the book of Proverbs. By highlighting some of the shared rhetoric of these texts, a new dimension of the relationship of the book of Ruth to the wisdom genre can be brought into focus.

\section{Ruth and Proverbs}

60; Michael V. Fox, Proverbs 1-9: A New Translation with Introduction and Commentary, AB 18 (New Haven, CT: Yale University Press, 2009), 17. Carol Newsom has appropriated the concept of "family resemblances" with regard to apocalyptic literature ("Spying Out the Land: A Report from Genology," in Bakhtin and Genre Theory in Biblical Studies, ed. Roland Boer, Semeia 63 [Atlanta, GA: SBL, 2007], 19-30). 
There is an obvious connection between the books of Proverbs and Ruth at the lexical level: Ruth is described as an אשת חיל, a "valiant woman" (Ruth 3:11). This is a phrase which, as a number of commentators have noted, occurs only here and in the book of Proverbs (Prov 12:4; 31:10). As well as the phrase אשת חיל, the texts share a number of other links. In Prov 31:29, the Valiant Woman is described as one who has עשו חיל, "acted valiantly." In Ruth, the women of Bethlehem declare

May the LORD make the woman who is entering your home like Rachel and Leah, both of whom built up the house of Israel! May you act worthily (עשה חיל) in Ephrathah and become famous in Bethlehem (Ruth 4:11).

The noun חיל occurs nine times in the Hebrew Bible in conjunction with the verb עשה ${ }^{31}$ so the distribution itself might not seem particularly significant - but in all other instances, the subject of the verb is masculine rather than feminine. Ruth and the Valiant Woman are the only female characters described as acting with חיל in the entire biblical corpus.

The book of Proverbs sets up various paradigmatic female characters: as well as the Valiant Woman, wisdom is itself personified as "Woman Wisdom."32 These figurations of

${ }^{31}$ Num 24:18; Deut 8:18; Ruth 4:11; 1 Sam 14:48; Pss 60:14; 108:14; 118:14-16; Prov $31: 29$.

32 Prov 1:20-33; 3:13-18; 4:1-9; 7:1-5; 8:1-36; 9:1-6; 14:1; cf. Job 28:1-28; Wis 6:1211:1; Sir 1:1-20; 4:11-19; 6:18-37; 14:20-15:10; 24:1-34; 51:13-30; Bar 3:9-4:4; 2 Esdr 13:5455. As Athalya Brenner has pointed out, the book of Proverbs is bookended by these figurations 
femininity are described in positive, aspirational terms. ${ }^{33}$ On the other hand, "Woman Strange" is a paradigm of immorality. This woman is variously described as רע. "evil," or זכריה or שרה While the meaning of the latter two lexemes essentially indicates foreignness, the descriptions of this character more often conjure up images of illicit sexual activity rather than an ethnic, legal or social status. ${ }^{35}$ The meaning of "foreign" in this case is essentially "otherness," employed to describe a character of "loose morals, devious charms and deviant religious convictions." 36 Woman Strange is sexually active outside of the bonds of marriage. She heightens her seductive charms through the application of perfumed oil (Prov 7:16-17). The sexuality of the Valiant Woman, on the other hand, is exclusively restricted to marriage. While many have noted that

of ideal women ("Some Observations on the Figurations of Women in Wisdom Literature," in $O f$ Prophets' Visions and the Wisdom of Sages: Essays in Honour of R. Norman Whybray on his Seventieth Birthday, ed. Heather A. McKay and David J.A. Clines, JSOTSup 162 [Sheffield: JSOT Press, 1993], 192-208).

${ }^{33}$ On "Woman Wisdom," see esp. Claudia V. Camp, Wisdom and the Feminine in the Book of Proverbs, Bible and Literature 11 (Sheffield: Almond Press, 1985).

${ }^{34}$ Prov 2:16-19; 5:3-8, 20; 6:24-26, 19, 32; 7:5-27; 22:14; 23:27-28.

${ }^{35}$ So Claudia V. Camp: "real ethnic foreign women and their gods are less a concern than all the metaphoric implications associated with them" (Wise, Strange and Holy: The Strange Woman and the Making of the Bible, JSOTSup 320 [Sheffield: Sheffield Academic Press, 2000], 29).

${ }^{36}$ Athalya Brenner-Idan, The Israelite Woman: Social Role and Literary Type in Biblical Narrative (2nd ed.; London: Bloomsbury, 2015), 122. 
Ruth ends her story as a Valiant Woman, few have recognized that Ruth begins as a נכריה (Ruth 2:10). Though this is literally the case with Ruth, as a woman from Moab, it also recalls the other of the book of Proverbs, the Strange Woman, the embodiment of otherness. In the course of the narrative, Ruth traverses the binary categories of female figuration from the book of Proverbs.

\section{Proverbs as Categorizing Discourse}

I argue that these connections do suggest that the book of Ruth can be- - and perhaps should beread in light of the book of Proverbs, and so the genre of wisdom literature. There is an intentionality in the specific terminology drawn upon in the characterization of Ruth as an חיל, along with the other language shared between these two books. As well as these lexical connections, there are thematic connections too, which I will go on to explore in the following. However, it is my contention that the relationship between Ruth to the wisdom tradition is both more extensive and more complex than commentators have previously realized. This is perhaps surprising given that the narrative prose form employed in the book of Ruth is so patently different than that found in Proverbs: the $m \bar{a} \check{s} \bar{a} l$, or "proverb." This term is explicitly given as a heading for the material assembled in Proverbs 1-9, 10-22:16, and 25-29. It is important to note, however, that the form also identifies compositions outside of the books of Proverbs (or Qoheleth and Job): Balaam's speeches in Numbers 23-24, for example, are described as mā̄̌āl. The $m \bar{a} \bar{s} \bar{a} l$ has been extensively unpacked by Jacqueline Vayntrub. Vayntrub describes the $m \bar{a} s \bar{a} l$ both formally and functionally. Formally, a $m \bar{a} \check{s} \bar{a} l$ is characterized by strict prosodic demands: parallelism. Functionally, a $m \bar{a} s ̌ \bar{a} l$ draws out generalizations about the world concerning persistent social and philosophical questions. But form and function are inherently linked: there 
is a relationship between content and prosody; "the structure outlines categories and makes claims with respect to the relationship between these categories. ${ }^{37}$ The term therefore identifies a type of speech performance governed by parallelism, the prosody of which establishes and categorizes relationships between categories. We see this both in the brief speech-units which make up the book of Proverbs, as well as in longer $m \bar{a} \bar{s} \check{a} \bar{l}$ compositions: as Vayntrub has shown, Balaam's speeches in Numbers 23-24 outline distinctions between divine and mortal, foreign and Israelite, and so on. ${ }^{38}$

An essential distinction developed in the book of Proverbs is between the wise and the foolish, so:

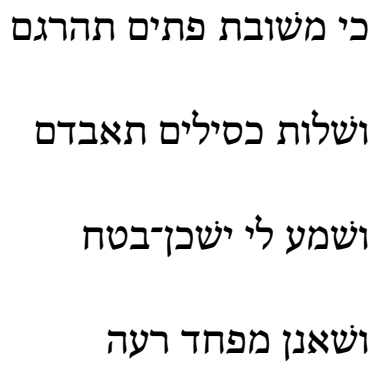

For the waywardness of the simpletons will kill them, and the careless ease of fools will destroy them.

But the ones who listen to me will live in security, and will be at ease from the dread of harm (Prov 1:32-33).

\footnotetext{
${ }^{37}$ Vayntrub, Beyond Orality, 117.

${ }^{38}$ Ibid, 103-43.
} 
Here the פסילים , פתמע, "fools," are contrasted with the "simpletons," and the ones who listen" - namely, the ones who listen to wisdom teachings, which is to say, the wise. This is part of a larger contrast between those who demonstrate correct behavior, and those who do not. The implication is that the latter category have failed to heed wisdom's teachings. The book therefore provides a demonstration of categories of right and wrong behavior, in all aspects of life. Correct treatment towards the poor and needy, ${ }^{39}$ towards children, ${ }^{40}$ or towards women ${ }^{41}$ are explicated in binary, unambiguous terms. A distinction is made between foreigner and Israelite, insider and outsider. ${ }^{42}$ Though primarily aimed at males, we find categories of right and wrong behavior for females too. We have already seen this in the discussion of the Valiant Woman in contrast to Woman Strange, which provide paradigmatic examples of ideal and non-ideal female roles. In these cases, the categorizing themes are fairly obvious; some, however, require more drawing out. For example, the book of Proverbs provides a paradigm for behavior towards one's parents:

נצר בני מצות אביך

ואל־תטש תורת אמך

My son, guard the commands of your father,

\footnotetext{
${ }^{39}$ Prov 14:21, 31; 17:15; 19:17; 21:13; 22:16; 28:27; 29:7; 31:9, 20.

${ }^{40}$ Prov 13:24; 19:18; 22:15; 23:13-14; 29:15, 17.

${ }^{41}$ Prov 6:29, 32.

${ }^{42}$ Prov 5:10; 6:1-3.
} 
and do not forsake the instruction of your mother (Prov 6:20).

This is related to a larger instructional context developed in the book of Proverbs in which knowledge is passed on, father-to-son. ${ }^{43}$ It is this focus on transgenerational transmission that has encouraged a particular reception of the book of Proverbs as educational material, and so it features frequently in discussions of scribal culture and education in the ancient Israelite context. ${ }^{44}$ Vayntrub, on the other hand, has incisively linked the importance of transgenerational succession to a larger theme found throughout biblical literature: the necessity of lineage with regard to a filial obligation to the dead, as a strategy for transcending individual death. Biblical literature attests to an active social interrelationship between the dead and the living, expressed in ritual form. ${ }^{45}$ As Vayntrub explains, these post-mortem acts of care "ensure the stability of the family line from one generation to the next. The son who cares for his father and succeeds him will, in turn, be cared for by his son, who will succeed him.." ${ }^{26}$ The devotional acts of living

${ }^{43}$ Prov $1: 8 ; 2: 1 ; 3: 1,21 ; 4: 1,10,20 ; 5: 1 ; 6: 20 ; 7: 1$.

${ }^{44}$ Vayntrub, "The Book of Proverbs and the Idea of Ancient Israelite Education," 97. For a critique of this approach to the reconstruction of ancient Israelite scribal culture, see Laura Quick, "Recent Research on Ancient Israelite Education: A Bibliographic Essay," CBR 13 (2014): 9-33.

${ }^{45}$ See esp. Francesca Stavrakopoulou, Land of Our Fathers: The Roles of Ancestor Veneration in Biblical Land Claims, LHBOTS 473 (London: T\&T Clark, 2012), 18-19.

${ }^{46}$ Jacqueline Vayntrub, "Like Father, Like Son: Theorizing Transmission in Biblical Literature," HeBAI 7 (2019): 500-26, here 501. 
relatives function to memorialize and so ensure that the memory and name of the individual survives across generations. In so doing, these ritual acts guarantee a post-mortem existence: they are a strategy for surviving death. Thus:

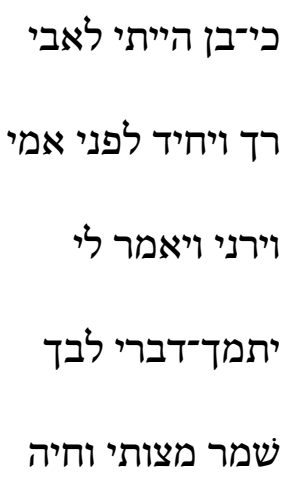

When I was a son to my father, a tender only child before my mother, he taught me, and said to me:

"Let your heart lay hold of my words; keep my commandments so that you will live" (Prov 4:3-4).

Here transgenerational succession in the form of passed-on teachings is explicitly related to a strategy for surviving death. In fact, knowledge transmitted across generational lines in the context of mortal anxiety is a key theme of Israelite wisdom literature more generally. ${ }^{47}$ It is

${ }^{47}$ So Vayntrub, "Wisdom in Transmission;" cf. also James L. Crenshaw, Old Testament Wisdom: An Introduction (rev. ed.; Louisville, KY: Westminster John Knox, 1998), 7; Don Matthewson, Death and Survival in the Book of Job: Desymbolization and Traumatic 
thus inherently important that one "builds a house." In Biblical Hebrew, the verb בנה can be used to denote the "building" of a dwelling or monument, but also a family, people, dynasty, or individual. In fact, the word בן, "son," has been explained as a derivative of "build."48 Certainly, the Ugaritic cognate bny, and Akkadian banû, mean both "to build," but also "to engender" and "to create." 49 To have a son is thus to build a house, a lasting monument which will ensure postmortem existence: thus in Proverbs it is wise to build up one's house (Prov 9:1; 14:1); while the requirement for transgenerational succession is explicit in a father's advice regarding his own son's fecundity (Prov 5:15-19).

But this strategy for post-mortem survival is a gendered one: only male offspring can guarantee the survival of the family name. This is felt keenly in Psalm 45, a hymn of praise in honor of a royal wedding. According to Cynthia Chapman, this hymn offers an idealized representation of the gender-specific values expected within patrilocal marriage:

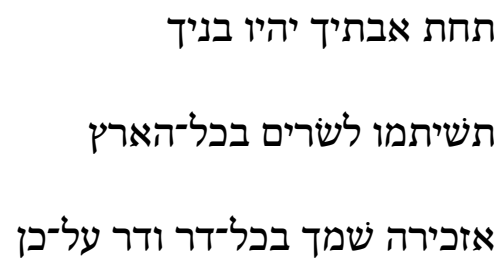

Experience, LHBOTS 450 (London: T\&T Clark, 2006); and Lindsay A. Askin, Scribal Culture in Ben Sira, SJSJ 184 (Leiden: Brill, 2018), 143-85.

${ }^{48}$ Siegfried Wagner, “banah,” TDOT 2: 166-8.

${ }^{49}$ Gregorio del Olmo Lete and Joaquin Sanmartín, A Dictionary of the Ugaritic

Language in the Alphabetic Tradition 1, trans. Wilfred G. Watson, HdO 67 (Leiden: Brill, 2003), 233-4; CAD 2, s.v. "banû." 


\begin{abstract}
Your sons will carry on the dynasty of your ancestors, you will make them princes throughout all land.

I will cause your name to be remembered from generation to generation, then the nations will praise you forever (Ps 45:17-18).
\end{abstract}

The man's place in his household is spoken of using terms that suggest "permanence, continuity, and the passing of an inheritance to sons in the form of a remembered name and land from generation to generation. ${ }^{50}$ Yet in the advice offered to the bride, the language does not suggest any kind of permanence. In fact, patrilocal marriage seems to require a break between the bride and her natal home:

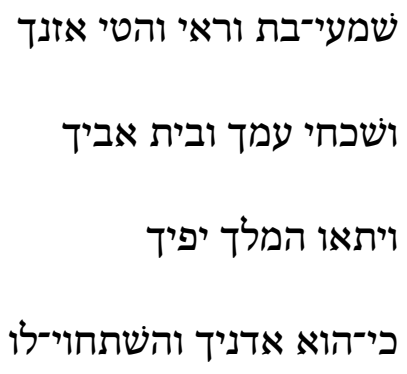

Listen, O Daughter! Observe and pay attention!

${ }^{50}$ Cynthia R. Chapman, The House of the Mother: The Social Roles of Maternal Kin in Biblical Hebrew Narrative and Poetry, ABRL (New Haven, CT: Yale University Press, 2016), 173. 
Forget your people and the house of your father!

Then the king will be attracted by your beauty.

After all, he is your master! Submit to him! (Ps 45:11-12).

There is, then, a disjuncture in the biblical account concerning the "persistence of being" along gendered lines. It is only by one's sons that an Israelite male might survive mortal oblivion, and so it is sons that are essential in the distinction between ideal and non-ideal ways to die.

For many, the $m \bar{a} \bar{s} \check{a} l$ is the prototypical form of Israelite wisdom literature, and therefore the book of Proverbs the characteristic example of Israelite wisdom. ${ }^{51}$ Yet as Vayntrub notes, the term actually occurs more frequently outside of the works traditionally assigned to the wisdom corpus, the speeches of Balaam as a case in point. ${ }^{52}$ Indeed, the books commonly grouped together as "wisdom literature" develop diverse literary forms. Thus while the $m \bar{a} \bar{s} \bar{a} l$ is important to the wisdom developed in the book of Proverbs, it is not exclusively characteristic of wisdom literature in general. This is important in the context of the discussion concerning which texts might be characterized as wisdom literature: if one is to make form alone the essential requirement, our interpretation of the evidence would necessarily be skewed. But when we talk about the wisdom of the book of Proverbs, it is important to note that it is this explicit form that characterizes the work. The book of Proverbs therefore utilizes the $m \bar{a} \check{s} \bar{a} l$ form and in so doing offers generalizations about the world and its actors in categories. Wisdom developed in this

${ }^{51}$ See esp. e.g. Katharine J. Dell, Get Wisdom, Get Insight: An Introduction to Israel's Wisdom Literature (Macon, GA: Smyth and Helwys, 2002), 7.

${ }^{52}$ Vayntrub, Beyond Orality, 75 
way is straightforward and unambiguous. A $m \bar{a} \bar{s} \bar{a} l$ is essentially categorizing discourse, and by articulating metaphysical questions in such a way, it makes a claim to provide the authoritative treatment of these issues. ${ }^{53}$ If one is to accept the wisdom tenets of the book of Proverbs, there are right and wrong ways to live - and to die.

\section{Ruth and Proverbial Wisdom}

On the other hand, the book of Ruth is organized as narrative: it tells the story of an Israelite named Naomi, and her Moabite daughter-in-law, Ruth. Naomi and family sojourn in the foreign land of Moab, where Naomi's sons take Moabite wives: Ruth and Orpah. In quick succession, first Naomi's husband Elimelech, and then her two sons, Mahlon and Kilyon, die - without leaving any heirs. Naomi returns to Bethlehem with Ruth, and the plot is resolved with the fulfilment of two biblical social practices: land redemption and levirate law (Leviticus 25; Deut 25:5-10). According to the obligations of the levirate law, the brother of a man who dies childless is required to marry the widow of the deceased, with the first-born child named for and treated as the son of the dead man. In the book of Ruth, Boaz is set up as a figure through which the Levirate obligation might be fulfilled, although there is a closer kinsman available. Ruth and Boaz marry, and the story concludes with the birth of their child.

A number of scholars have found it problematic that the contours of these two sets of laws in the book of Ruth diverge significantly from their precedents in the Torah. ${ }^{54}$ However, I

${ }^{53}$ See Ibid, 70-71, 145, 164, 170, 172.

${ }^{54}$ See Yair Zakovitch, Das Buch Rut: Ein jüdischer Kommentar, SBS 177 (Stuttgart: Verlag Katholisches Bibelwerk, 1999), 21-24. This is despite the fact that in the book of Ruth, 
would argue that the point of the narrative is not to demonstrate the workings of these laws within a narrative setting. Neither is it to provide a functional demonstration of the values and virtues embodied by the Valiant Woman. Rather, the story of the book of Ruth and the legal conventions invoked within it function as a way for the narrative to think through and problematize some of the categories of correct behavior articulated in wisdom literature. The characterization of Ruth is essential in this context. The categorical distinction between native and foreign, outsider and insider, is challenged by the figure of Ruth, a Moabitess who is also equal to the ancestors of Israel (4:11-12). ${ }^{55}$ Crucially, the author of Ruth explicitly draws upon

the legal precedent in Deuteronomy 25 is not only alluded to, but is in fact extensively quoted from. See Georg Braulik, "Das Deuteronomium und die Bücher Ijob, Sprichwörter, Rut," in Die Tora als Kanon für Juden und Christen, ed. Erich Zenger, HBS 10 (Freiburg: Herder, 1996), 61136.

${ }^{55}$ In this context, we might also refer to the genealogical material that closes the book (Ruth 4:18-22). The genealogy recalls the תלדת formula otherwise used in the Patriarchal narratives of the book of Genesis: אלה תלדת, "these are the generations of..." This combination of תלדת, "generations," with the demonstrative article אלה occurs only in Gen. 2:4; 6:9; 10:1; $11: 10,27 ; 25: 19$; Num. 3:11 - and here in the book of Ruth. The genealogy is almost universally understood to be secondary (see e.g. Campbell, Ruth, 173; Gillis Gerleman, Ruth: Das Hohelied, BKAT 18 [2nd ed.; Neukirchen-Vluyn: Neukirchener, 1981], 7; John Gray, Joshua, Judges, Ruth, NCB [Grand Rapids: Eerdmans, 1986], 403; Hans Wilhelm Hertzberg, Die Bücher Josua, Richter, Ruth, ATD 9 [Göttingen: Vandenhoech and Ruprecht, 1969], 278-70; Nielsen, Ruth, 96; Sasson, Ruth, 179-186; Würthwein, Die Fünf Megilloth, 20-21). Nevertheless, it clearly shows 
the language of Proverbs in order to develop the character. But Ruth is both a נכשת and an חיל. The paradigmatic figurations of femininity from the book of Proverbs, Woman Strange and the Valiant Woman, are mediated via Ruth, who models characteristics of both figures. As Gregory Goswell has noted, both Ruth and the Valiant Woman are described as showing חסד, "kindness" (Ruth 3:10; cf. Prov 31:26). ${ }^{56}$ Yet at the same time, many commentators have noted the sexual implication of the interaction which takes place between Ruth and Boaz in chapter 3 of the book. ${ }^{57}$ Like the Strange Woman, Ruth heightens her seductive powers through the application of perfumed oil (Ruth 3:3; cf. Prov 7:16-17), before visiting a man alone, at night. She lies down upon the threshing room floor, ${ }^{58}$ and either uncovers a part of his body ${ }^{59}$ or

that already in the earliest reception of the story of Ruth, the character was being understood as on par with the matriarchs of Israel - despite her foreign status.

${ }^{56}$ Goswell, "Is Ruth Also Among the Wise?" 122.

${ }^{57}$ Lilliam Klein describes Ruth as engaging in "sexual manipulation" (From Deborah to Esther: Sexual Politics in the Hebrew Bible [Minneapolis, MN: Fortress, 2003], 4). André LaCocque considers Ruth to be making use of "the most controversial resources of her femininity" (The Feminine Unconventional: Four Subversive Figures in Israel's Tradition, OBT (Minneapolis, MN: Fortress, 1990], 2).

${ }^{58}$ Tod Linafelt and Timothy Beal have argued that the threshing room was a location particularly appropriate for a sexual tryst (Ruth and Esther, Berit Olam [Collegeville, PA: The Liturgical Press, 1999], 48).

${ }^{59}$ The lexeme in question is מרגלות, with the meaning of something like "the place of the feet." In Dan 10:6, the word is used in parallel to "arms," hence the meaning in Daniel is 
undresses herself (Ruth 3:4,7). ${ }^{60}$ There is little in the book itself that would actually suggest that Ruth is behaving in any ways characteristic of the woman described in the acrostic poem in Proverbs 31. Even proponents of this reading strategy have difficulty in making the connection: Katherine Doob Sakenfeld, for example, writes that it "is easy to imagine” that, as Boaz's wife, Ruth "would become the epitome of the wife described in Proverbs." 61 It is only by imaginatively extended the narrative beyond the close of the book that Sakenfeld can come up

most probably "legs." The more usual word for "foot" in Biblical Hebrew, רגל, can be utilized as a euphemism for genitalia ( $B D B$, s.v. "רֶֶּל"), and accordingly a number of commentators suggest that Ruth is actually undressing Boaz here. See e.g. Sasson, Ruth, 67; and Phyllis Trible, "Ruth in the Hebrew Bible," in Women in Scripture: A Dictionary of Named and Unnamed Women in the Hebrew Bible, the Apocryphal/Deuterocanonical Books, and the New Testament, ed. Carol Meyers (Grand Rapids, MI: Eerdmans, 2000), 147.

60 The object of the verb גלה, "uncover," is unspecified in 3:4. In the other instances where the verb גלה occurs in the pi 'el stem, it is usually a female body that is uncovered (Lev 18:16-19; 20:11, 17-21; Deut 23:1; 27:20; Ezek 16:37; 22:10; 23:10, 18; Nah 3:5; Hos 2:12). Accordingly, Jeremy Schipper interprets Naomi’s speech as an instruction for Ruth to undress and lie down at Boaz's feet (Ruth: A New Translation with Introduction and Commentary, AB 7D [New Haven, CT: Yale University Press, 2016], 143; see also Nielsen, Ruth, 66-71). Indeed, Ellen van Wolde argues that since Ruth requests that Boaz spreads his cloak over her (3:9), the implication is that Ruth has herself disrobed (Ruth and Naomi [London: SCM, 1997], 70).

${ }^{61}$ Sakenfeld, Ruth, 62. 
with a Ruth who is truly representative of the Valiant Woman ideal. The paradigms of the נכריה and the אשת חיל are challenged by Ruth, who inhabits both of these binary figurations.

Gender itself is subverted. Ruth takes on various roles that conform more to masculine than to feminine expectations. She gleans in the fields, the danger of which is made apparent by Boaz's request that she stay near to his servants (2:8). Ruth's activities are precarious and put her in the publicly visible sphere. Accordingly, there are a number of instances in which Ruth, as well as Naomi and Orpah, are described using grammatically masculine forms. ${ }^{62}$ On the other hand, males are twice described using a feminine plural pronoun. ${ }^{63}$ Typically, gender discord in Biblical Hebrew has been understood as a weakening in the distinction of gender in which the feminine plural suffix was subsumed under its masculine counterpart under the influence of colloquial language. Accordingly, it has been taken as a characteristic of Late Biblical Hebrew. ${ }^{64}$

${ }^{62}$ Ruth $1: 8,9,11,13,19,22 ; 4: 11$.

${ }^{63}$ This occurs in Naomi’s speech to Orpah and Ruth: "If I should say I have hope, even if I should have a husband this night and should bear sons, for them (להן) would you therefore wait till they were grown? For them (להן) would you therefore refrain from marrying?" (Ruth 1:13). An alternative reading is to take the lexemes in question as the Aramaic particle להן, "therefore" (cf. Dan 2:6, 9; 4:24). Although gender discord in this direction is much less common in Biblical Hebrew (additional instances occur at Ezek 42:14; Nah 2:5; Eccl 7:27), Andrew Davis notes that the versions unanimously support the reading "for them" ("The Literary Effect of Gender Discord in the Book of Ruth,” JBL 132 [2013]: 495-513, here 499).

${ }^{64}$ See e.g. GKC §135o; Gary Rendsburg, Diglossia in Ancient Hebrew, AOS 72 (New Haven, CT: American Oriental Society, 1990), 49; G.R. Driver, "Colloquialisms in the Old 
A second explanation draws upon the dual ending forms -humā attested in Classical Arabic, and $-h m$ in Ugaritic, explaining the use of apparently masculine plural pronouns for female antecedents as vestiges of a common dual ending in Proto-Central Semitic - and so characteristic of early texts. ${ }^{65}$ Both explanations have variously been forwarded in order to explain discordant gender in the book of Ruth. ${ }^{66}$ But neither hypothesis can account for the use of feminine pronouns with male antecedents $(1: 13)$. Nor do these explanations take into account why gender discord in the book of Ruth occurs - sometimes even in the same verse-with correct forms. An alternative suggestion is that discordant forms have been consciously utilized by the author of the

Testament," in Mélanges Marcel Cohen: Etudes delinguistique, éthnographie et sciences connexes offertes par ses amis et ses élèves à l'occasion de son 80ème anniversaire, ed. David Cohen, Janua Linguarum 27 (Paris: Mouton, 1970), 232-9; and Jaakov Levi, Die Inkongruenz im biblischen Hebräisch (Wiesbaden: Harrassowitz, 1987).

${ }^{65}$ E.g. Jacob M. Myers, The Linguistic and Literary Form of the Book of Ruth (Leiden: Brill, 1955), 20.

${ }^{66}$ For the appeal to the phenomenon of gender neutralization see e.g. Joüon $§ 149 \mathrm{~b} ; G K C$ §135o; and Donald R. Vance, A Hebrew Reader for Ruth (Peabody, MA: Hendrickson, 2003), 910, 12. Preferring the linguistic retention of the dual are e.g. Campbell, Ruth, 65; Hubbard, The Book of Ruth, 4; and Nielsen, Ruth, 45. Jacob Myers utilizes this in order to argue for an early dating for the composition of Ruth, concurrent with its narrative setting in the period of the Judges (The Linguistic and Literary Form of the Book of Ruth, 20). 
book of Ruth for literary effect. ${ }^{67}$ Naomi's sons, both actual and potential, have been as beneficial to her as daughters would have been: they have left her just as bereft of offspring as if she had had daughters who had married and moved away to the houses of their husbands. Ruth, on the other hand, is praised as more valuable to Naomi than seven sons (4:14). The categories of correct behavior for foreigner and native, the Valiant Woman and Woman Strange-even men and women — are explored and destabilized throughout the narrative.

But most importantly, I would argue that central to the book of Ruth is a mediationeven an abortion — of an essential idea voiced in wisdom literature more generally: mortal anxiety, and the desire to "build up one's house" as a strategy for surviving mortal oblivion. Many scholars interpret the law of levirate marriage to do with the supposed benefit which it would have for the widow. But Boaz's speech concerning his claim to Ruth appeals instead to male interests: "His proposition is not worded in terms of meeting the physical needs of impoverished widows; rather, he focuses on the incorporeal male needs - the sacred male name

${ }^{67}$ So Timothy H. Lim, “The Book of Ruth and Its Literary Voice," in Reflection and Refraction: Studies in Biblical Historiography in Honour of A. Graeme Auld, ed. Robert Rezetko, Timothy H. Lim and W. Brian Aucker, VTSup 113 (Leiden: Brill, 2007), 261-82; idem, "How Good Was Ruth's Hebrew? Ethnic and Linguistic Otherness in the Book of Ruth," in The “Other” in Second Temple Judaism: Essays in Honor of John J. Collins, ed. Daniel C. Harlow et al. (Grand Rapids, MI: Eerdmans, 2011), 111-2; cf. Davis, "The Literary Effect of Gender Discord in the Book of Ruth." 
and lineage. ${ }^{98}$ Levirate marriage thus promised the Israelite male a kind of generational immortality: the preservation of male name (and property, hence the necessity of linking the levirate law with the law of redemption in the book of Ruth) throughout the generations. It relates, therefore, to the importance of the endurance of the family as an entity with "name."

Elimelech's post-mortem survival seemed ensured by the birth of his two sons. Yet their inability to fulfil this promise is explicit in their very names: מחלון, and מליון, the former from the root חלה, "be weak, sick," accomplished, spent. ${ }^{, 70}$ Both names have an - ון suffix used for diminutives, suggesting the translations "Sickling" and "Weakling." With their death, the central conflict of the plot is established: who will ensure the post-mortem survival of the house of Elimelech? It seems at first that, through the practice of the levirate law and the law of redemption, both Elimelech's family name and property have been given a second chance at survival. Indeed, Ruth is praised that she become like "Rachel and Leah, who together built up the house of Israel" (4:11): the

${ }^{68}$ So Danna Nolan Fewell and David M. Gunn, "Boaz, Pillar of Society: Measures of Worth in the Book of Ruth," JSOT 45 (1989): 45-59, here 59 n. 33. Cf. Simeon Chavel, Oracular Law and Priestly Historiography in the Torah, FAT II/71 (Tübingen: Mohr Siebeck, 2014), 253.
${ }^{69}$ BDB, s.v. "חָלָלה".

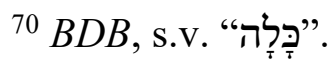


focus is clearly on building up ancestry. ${ }^{71}$ Yet the outcome of the narrative is not quite what we would expect. Boaz is not the closest kinsman of the house of Elimelech. The child born of Ruth and Boaz is not named for the dead house of Elimelech. In fact, there are a number of subversions or even reversals of our expectations in the story. Though the story has been couched as a problem in the survival of the male house of Elimelech, it is actually the women who name the child (4:17). Ruth is praised as more precious to her mother-in-law than seven sons $(4: 15)$. Yet thereafter she disappears from the narrative. The focus switches from Ruth to her mother-in-law, and the narrative concludes with the declaration that "a son has been born to Naomi" (4:17). In fact, it is not the father's house which is the locus of social organization, but the house of the mother (1:8). At every juncture, our expectations for the successful continuity of the house of Elimelech are subverted.

\section{Conclusions}

Consequently, my interpretation of the book of Ruth is not as an actualization or exegesis of the Valiant Woman of Prov 31:10-31. Indeed, the focus of the description of the Valiant Woman is upon the "fruit of her hands" (31:31), namely her skill and agency in various economic activities that benefit her family and the larger community - a theme entirely absent from the book of Ruth. Accordingly, neither is the narrative intended to motivate behavior reminiscent of the Valiant Woman. Instead, I argue that the book of Ruth is an extended problematization of the

${ }^{71}$ Jacqueline Vayntrub has also explicitly connected the story of Ruth to the issue of transgenerational succession and survival, arguing that "the birth of Obed solidifies the postmortem, trans-generational line.” See Vayntrub, "Like Father, Like Son,” 525. 
limits of conventional wisdom expressed in categorizing discourse. It draws upon the language of Proverbs, only to explore and destabilize various wisdom conventions and categories: native and foreign, insider and outsider, male and female, the Valiant Woman and Woman Strange, even life and death. Ruth doesn't necessarily offer any answers to the metaphysical dimensions posed by these categories, but rather demonstrates the limitations of binary ethics. This reading strategy explains some of the problems which commentators have noted in the story: female characters are described with male pronouns, and vice versa; Ruth is essential to the resolution of the plot and yet fades entirely from view at the end of the narrative, where Naomi becomes the focus; legal tenets are recalled and yet only imperfectly put into practice. Our narrative expectations are subverted at every juncture, just as are the categories of conventional wisdom.

This interpretation of the book of Ruth brings it much closer to the other two texts which make up the conventional corpus of Israelite wisdom literature: the books of Job and Qoheleth, which also reflect upon and complicate conventional wisdom. ${ }^{72}$ Indeed, the critique of traditional wisdom expressed in Job and Qoheleth has seen these texts described by some scholars as

${ }^{72}$ For a recent treatment of the books Qoheleth and Job as a critique of conventional wisdom, see Susan Niditch, The Responsive Self: Personal Religion in Biblical Literature of the Neo-Babylonian and Persian Periods, ABRL (New Haven, CT: Yale University Press, 2015), 32-52. For a comparison of the book of Job to "traditional" wisdom literature, see Katharine J. Dell, The Book of Job as Sceptical Literature, BZAW 197 (Berlin: de Gruyter, 1991), 63-88. On the book of Qoheleth as a critique of conventional wisdom teachings, especially as can be found in Proverbs 1-9, see Konrad Schmid, The Old Testament: A Literary History, trans. Linda M. Maloney (Minneapolis: Fortress, 2012), 191. 
"wisdom in revolt." 73 These alternative voices engage in a corrective dialogue with the traditional wisdom tenets expressed by the book of Proverbs. ${ }^{74}$ Yet they do so using remarkably diverse literary forms: thus while Qoheleth's critique is developed through the subversive reuse of traditional wisdom forms, in Job the critique is expressed via a personal account of the underserving sufferer, expressed in poetic dialogue. In this essay, I have argued that the formal characteristics of wisdom literature can be widened further still. In the same way that the wisdom of Qoheleth and Job is revolutionary when compared to the conventionalized wisdom developed in the book of Proverbs, Ruth too provides a revolutionary exploration of the wisdom genre only expressed in prose. In fact, like the $m \bar{a} \bar{s} \bar{a} l$ in Proverbs - in which form and function are inherently linked, with the outcome that metaphysical questions are expressed in binary, authoritative terms - form is also essential to the development of Ruth's critique: the narrative genre allows for a discursive exploration of the constraints of categorizing discourse. The book of Ruth can indeed be related to wisdom literature - but perhaps in a more complex and nuanced way than is usually allowed.

${ }^{73}$ Gerhard Von Rad, Weisheit in Israel (Neukircehn-Vluyn: Neukirchener Verlag, 1970), 306-8; R.B.Y. Scott, The Way of Wisdom in the Old Testament (New York: Macmillan, 1971), 136; Leo G. Perdue, Wisdom in Revolt: Metaphorical Theology in the Book of Job, Bible and Literature Series 29 (Sheffield: Sheffield Academic Press, 1991), 260-73.

${ }^{74}$ For the concept of a "dialogue" between the books of Proverbs, Job, and Qoheleth, see David J.A. Clines, Job 1-20, WBC 17 (Dallas: Word Books, 1989), ixi. 